\title{
The weapon of mousikē in Euripides' Cyclops
}

\author{
András Kárpáti \\ (University of Pécs)
}

\begin{abstract}
The aim of this paper is to explore the poetic function of mousikē in Euripides' Cyclops. The plot unfolds through flashes of playful utterances that relate to Greek song culture. Each of these subversively pokes fun at the dichotomy between the civilised and the uncivilised. Forms of and references to choreia and mousike, embedded in the performative context of the satyr-drama, function on two levels: on the level of plot (traditional myth put on stage), they constitute a weapon against the giant; on the level of community and emotions, they reveal that, by the end of the $5^{\text {th }}$ century, protection offered by culture becomes vulnerable.
\end{abstract}

\section{Keywords}

Euripides; Cyclops; mousikē; choreia; Greek song culture; satyr-play; satyr-drama 


\section{Introduction}

In Euripides' Cyclops, mousikē was designed as a vehicle for exploiting the generic theatrical conventions for space by extending their boundaries from the visual to the aural. ${ }^{1}$ As for the conventions for theatrical space, the action takes place in front of the cave of Polyphemus in Sicily, close to the Mount Etna. ${ }^{2}$ Since the cave was represented by the $s k \bar{e} n \bar{e}$, the audience who understood and valued dramatic conventions knew right at the beginning ${ }^{3}$ that a plot with a hero's escape from a cave as a key motif - in the Odyssey as well as in folk tale type ${ }^{4}$ - unfolds outside of the cave. From our perspective, this preliminary knowledge that is rooted in performance conventions is essential for the following reasons. Dramatic performances are governed by their own conventions and rules, similarly to pictorial representations. Both media necessarily diverge from the logic of epic narration. As the Polyphemus story's synoptic narrative is self-explanatory and makes sense for the viewer of a vase painting, ${ }^{5}$ the loosening of the strict logic of inside vs. outside and projecting both dimensions into the space of the performance is also self-evident for the audience of the Cyclops. Thus, upon entering the self-contained world of the satyr-drama, it would be unfair to ask how is it possible that Odysseus could enter the cave in front of our eyes and could go out from it just to tell the satyrs how his men were devoured by Polyphemus, while his men (mute characters in the performance) could not escape? When a myth is told by a dramatist in a performance, the key motif of the tale ('escape from a cave') could be given a new form: here and now Odysseus is locked in the cave in a way that he is able to tell the story outside, while he is inside. Mousike works in a similar way in this play. 'Defeating the monster' (another key motif of the tale), here and now, could be done with the weapon of mousike. It is possible by the susceptibility of theatrical conventions. In this play, all emphasis was put on culture represented by different forms of mousike. The plot unfolds through short flashes of various possibilities of utterances offered by Greek song culture and choreia: non existing hyporchèma, cacophonic anti-sympotic song, aborted kōmos, defective amoibaion, parodistic makarismos, perverted hymenaios, unvoiced magic epōdè, unsung paian.

1 For introductions with further literature, see KPS (pp. 431-441); OSC (pp. 1-75); Laemmle (2013: pp. 327-350); HL (pp. 1-46). An original approach to the relationship of comedy and the satyr-play: Shaw (2014). The literature on satyr-play is extensive, I refer here only to Seaford (1984); Voelke (2001); Harrison (2005); Laemmle (2013); Griffith (2015).

2 A notable emphasis is on the venues: Aetna is mentioned eleven times, Sicily four times. This (and other arguments) can imply a later date (after the Sicilian disaster of 413). On the dating of Cyclops, see OSC (pp. 39-41) and HL (pp. 38-47) who propose 408 BC.

3 See Revermann (2006).

4 In folk tale type ATU 1137 (cf. note 15, below), escape from confinement through disguise (K521.1) is a key motif. This motif seems to be more common than the act of getting the giant drunk. See for example: Hansen (2002: pp. 289-300, with further literature on p. 291) and Aguirre \& Buxton (2020: pp. 8-14), cf. Calame (1977).

5 For the iconography, see Touchefeu-Meynier (1997: pp. 1011-1019). On the relationship between image and text (related to the Polyphemus myth), see Aguirre \& Buxton (2020: pp. 19-22). Cf. Squire (2009: pp. 300-338), and Giuliani (2013: pp. 70-77, 131-138) both with earlier literature. 
When Odysseus comes out of the cave in the middle of the performance, he details how the ogre chopped up, cooked, roasted and ate his two men. When the giant was done - tells Odysseus - he burped, and an idea came to me: I should offer him wine. This he accepted and drank it all at once and I refilled, knowing that he would be knocked out and then I could punish him.

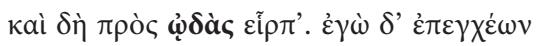

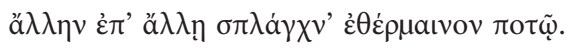

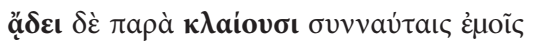

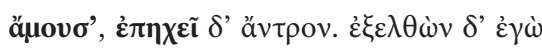

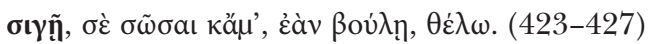

"Sure enough, he started singing, while I kept pouring out one cup after another and warmed his innards with the drink. So he sings his cacophony (amousa) next to my fellow sailors who are weeping, while his cave resounds with it. Now I've come out quietly, because I want to save you and me, if you're willing."

Odysseus' account uses meta-musical language. ${ }^{7}$ However, the seed for amousa had already been sown earlier in the play. After Odysseus and his men arrive, he wants to know who live there. Silenus' answer relates to mousike even at this early point of the play: the cyclopes have no society and no cities, they live alone in their caves. They are not familiar with grains or the juice of grape. He then concludes: ä $\chi 0 \rho o v$ oikoṽoı $\chi \theta$ óva (124, "they inhabit a land where there is no dancing").

For the Greeks, choreia as the performance of identity and moral values of the city was fundamental to civic education. 8 "Dancing in a chorus, or simply watching one perform, represented an immersion into the values of the community, and a participation in its

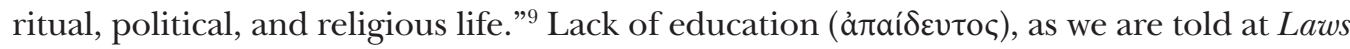
$654 \mathrm{a} 9$, is equivalent with lack of choral training (ảxó $\rho \varepsilon v \tau o \varsigma) .{ }^{10}$ What the audience will then see one after another on the stage is the uniquely parodied evocation of different forms of choreia. Not only Odysseus, but also the audience who enjoyed the choreia (and its subversive quality) performed by the satyrs are thus fully aware of the consequence and meaning of the cyclopes' land being achoros. This is how Odyssean trickery is performed on stage. If the land of the cyclopes is achoros, then, on the stage, bound by the constrains of performance conventions, choreia and mousike may be suitable to be used as a weapon against the giant. And even if Odysseus cannot draw on the satyrs to gather

$6 \quad$ All translations of E. Cyc. are taken from OSC.

7 Cf. Weiss (2018: p. 15).

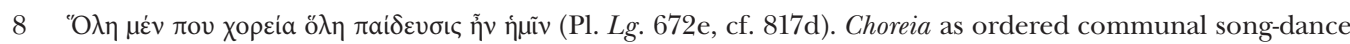
is the performance of the identity and fundamental moral values of the dwellers of Greek cities. See the suggestive title of Prauscello (2014) "Performing Citizenship...", the second part of the book discusses the tradition of choreia.

9 Swift (2010: p. 2).

10 Cf. Prauscello (2014: p. 149). 
the necessary bravery to blind the monster, these mousikoi satyroi, who are of course welltrained in choreia, can be of serious help.

The dweller of an achoros land, who, upon first tasting wine and breaking out in singing, can only sing something that is amousa: a museless non-song. ${ }^{11}$ Thus, that was there as a germinal idea in achoros (124) earlier in the play, could manifest itself now in this museless (amousa) song (426). Singing and drinking wine, however, automatically lead to the idea of symposium. Consequently, the cultureless cyclops as a symposiastes and, following the symposium, as kōmastēs was at first conceived in the imagination of Odysseus and of the audience, by their own experiences. Later in the play, symposium and kommos actually appear on stage.

Here, Odysseus - and Euripides - kills three birds with one stone. At the level of the plot: there is a plan! At the level of the binding conventions of performances: the motif of being locked in a cave, a core element of the Homeric version, became utterly fluid. And, finally, at the level of Greek performance culture: the figure of the singing Polyphemus was born. ${ }^{12}$ It seems worth to give a short overview here about Polyphemus' musical career, if any, on the Athenian stage.

\section{Before Euripides' Cyclops}

Polyphemus the one-eyed giant became one of the rising stars of song-and-dance performances in the $5-4^{\text {th }}$ centuries BC. We know of no less than twelve pieces, in which cyclopes were given a part (Polyphemus may have been the singing protagonist in eight to ten of the twelve): six comedies, three dithyrambs, two satyr-plays, and a nomos, ${ }^{13}$ in all of them effect was reached, among other things, through musical mimesis. ${ }^{14}$

The story of Polyphemus, combining fairytale-like motifs,${ }^{15}$ had already had a comic tinge in the Odyssey ${ }^{16}$ as well as in Sicilian comedy. From the three remaining lines of Epicharmus' Cyclops (cc. 485-470 BC) emerges the figure of typical gluttonous heavy

11 Cf. Halliwell (2012: pp. 19-21).

12 See nn. 31 \& 52, below. Cf. LeVen (2014: pp. 233-242); Power (2013); Aguirre \& Buxton (2020: pp. 214-217).

13 The twelve works chronologically (as far as it is possible to set up a chronology): 1. Epicharmus: Cyclops, Doric comedy, between 485-470 BC; 2. Callias (or Diocles?): Cyclopes, comedy, 434 (?) BC; Cratinus: Odysseuses, comedy, 440-435 BC; 4. Aristias: Cyclops, satyr-play, between 440-430 (?) BC; 5. Euripides: Cyclops, satyr-play, after 415 (?) BC; 6. Philoxenus: Cyclops, dithyramb, 390/89 BC; 7. Timotheus: Cyclops, nomos (dithyramb?), 400-380 BC; 8. Nicochares: Galatea, comedy, 388-380 (?) BC; 9. Stesichorus II: Cyclops, dithyramb, 380-350 BC; 10. Oiniades: Cyclops, dithyramb, 350 BC 380-350; 11. Antiphanes: Cyclops, comedy, 380-350 BC; 12. Alexis: Cyclops or Galatea, comedy, ca. 350 BC. Cf. Mastromarco (1998).

14 Cf. Arist. Po. 1447 a25, b25 with 1448 a 10 and 20.

15 Hom. Od. 9. 106-542. Folktale type ATU 1137: Uther (2004: Part. II., p. 45). See Calame (1977); Heubeck \& Hoekstra (1989: p. 19); Anderson (2000: pp. 123-131) and Aguirre \& Buxton (2020: pp. 8-13).

16 The giant is ugly, scary and laughable (as for his appearance, mode of life, and intellectual capacities), for which he is ridiculed by Odysseus. Motifs pertaining to comedy: trickery (the use of the name "Nobody"), getting the giant drunk, and escaping under the sheep. 
drinker. ${ }^{17}$ It is not known to what extent Sicilian comedy used music and song. ${ }^{18}$ However, three Athenian plays are known from between 440-430 BC, which staged cyclopes through the medium of mousike. In Callias's Cyclopes, choreutai were cyclopes performing songs and dances on the orchēstra. ${ }^{19}$ The plot is unknown, but the few extant lines reveal that delicious, festive meals, the blessing of wine, dance figures, and the kottabos play are mentioned. Though the drinking of wine and intoxication play a key role in the story of Polyphemus as well as in Euripides's play we see Polyphemus at a symposiastic scene, the fragments of Callias' comedy are insufficient to prove that motifs of the episode of the Odyssey 9 are present in the plot (though we cannot exclude this possibility either). However, the plot was built up though, the audiences inevitably projected the most famous Homeric monophthalmos into the aural and visual space created by a performance of dancing cyclopes, even if he himself was not present on the stage.

He was there however in Cratinus' Odysseis performed at the Dionysia between 440 and 435 BC. ${ }^{20}$ The fragments clearly show that Cratinus staged the parody of Homer's Cyclopeia, what is more, an undatable treatise on the genre of comedy refers to it as a persiflage of the Odyssey. ${ }^{21}$ There are compelling arguments that the play could began with a surprising prologos-parodos. ${ }^{22}$ The members of the chorus, Odysseus and his crew - holding a boat prop in front of them in front of them (a spectacular theatrical innovation?!) - try to lift each other's spirit, while battling with the tempestuous sea and the winds (frs. 143, 151). ${ }^{23}$ Cratinus created a double fictive space in this dialogic anapaestic parodos. ${ }^{24}$ When the chorus appeared on stage, the audiences could see a sea storm on the orchēstra, evoking the plot of the Odyssey, symbolizing the island of the cyclopes that for Odysseus and his men was an unknown place, whereas for the viewers it was something entirely familiar. The skēnē's painting depicted the well-known cave of Polyphemus. The journey on the sea and the tempest transport us into the world of tales: to the Known Unknown. Civilization is known for the audience, whereas the unknown is considered uncivilized and barbaric. Whether this spatial distance had been transformed into the dynamics of (a seemingly?) unbridgeable cultural distance already in Cratinus' play, as later in Euripides', can only be conjectured from the fragments of the play. The possibility, however, cannot be excluded that Cratinus' Polyphemus came

17 PCG I. (pp. 49-51) and Olson (2007: pp. 52-53). Cf. Shaw (2014: pp. 63-64).

18 As for the metres of the Epicharmus fragments: there is no "lyric" meter in them that would suggest chorus or singing in the plays of Epicharmus, see Olson (2007: p. 7) and Pöhlmann (2015).

19 PCG IV. (pp. 42-45) (F 5-13); Storey (2011: pp. I. 152-156). The date of the first performance can be estimated based on IG Urb. Rom. 216.1-6: 434 BC (Dionysia).

20 PCG IV. (pp. 192-200) (F 143-157); Storey (2011: pp. I. 332-340). It is possible that from among the Athenian cyclops comedies, the earliest one is Cratinus', but since it is not known whether Callias' featured Polyphemus next to the chorus of the cyclopes or not, and since the dating of the first performance is uncertain (see n. 13. above), it seems only logical to discuss Cratinus' comedy after Callias'.

21 Platon. Diff. com. (Koster 1975: pp. 5.51-52).

22 Bakola (2010: pp. 234-246).

23 Parallels to ships on stage: Bakola (2010: p. 240, n. 29).

24 Cf. Bakola (2010: p. 238). Anapaestic parodoi: Ar. Nu. 263-456 \& Ra. 316-459. Dialogic parodoi: Ar. Av. 209-450 and Th. 295-382. 
to be in a conflict, similarly to his counterpart in Euripides's play, with the Greek culture essentialized through mousike whilst getting intoxicated by Odysseus.

What is known however, is that in F 146 and F 150 the source of humour is the incongruence between Polyphemus' barbaric lifestyle and his civilized use of language. He identifies the wine with its giver, Maron (known from the Odyssey) by naming it after him (similarly to Euripides' Polyphemus). ${ }^{25} \mathrm{He}$ also uses sophisticated language, giving away his deep culinary knowledge, to describe how he plans to chop up, skewer, season, soften and fry Odysseus and his men, dip them in garlic vinegar sauces and finally eat the shipmen cooked to perfection. The Athenian audience could remember the difference: in the Odyssey he "chewed them up just like a mountain lion - innards, flesh, and marrow - leaving nothing." 26

Aristias' satyr-play Cyclops is also dated to the years between 440 and 430 BC. ${ }^{27}$ Only one line was preserved in multiple sources, one of which informs us that the following words (later becoming a proverb) were uttered by Odysseus to Polyphemus: ả $\pi \dot{\omega} \lambda \varepsilon \sigma a \varsigma$

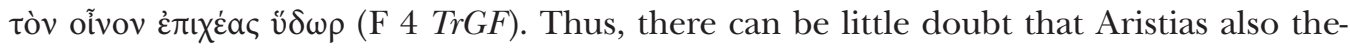
matized the appropriate way of drinking wine, conforming to the traditions of Greek symposia. ${ }^{28}$ In Athens in the $5^{\text {th }}$ century BC, as it was commonly held, only the uncivilized, barbaric people drank pure wine, get drunk and trespass social boundaries, as the centaurs did in the myth of Centauromachy. At the moment of the construction of the West pediment of the Temple of Zeus at Olympia in the $460 \mathrm{~s} \mathrm{BC}$, the figures of the Centauromachy evoked feelings of proud superiority of the Greek civilization as opposed to the barbarians, who consumed wine in the 'wrong way' and who were to be substituted in the viewer's mind with the Persians conquered not long before. ${ }^{29}$ But the memory of the Greek civilization's superiority was cast in a different light after a couple of decades, during the Peloponnesian War: what was really hidden behind the par excellence Greek civilization, the face (or mask?) of the culture of symposia and mousik $\vec{e}$ ? Was it the experience of war and politics within (and outside of) Athens? Or the greed for power defying all values, the brutality that destroys one another? If this was indeed the case, it must have been increasingly hard to cover with the typical elements of Greek refinement: with the mode of life and with the mousike .

The recognition of the ambivalence of cultural superiority, understanding of its autotelic values and vanity, however, did not override the proud self-awareness characterizing the first half of the century, only made it controversial. Based on the sole line from Aristias' satyr-play, deeming Polyphemus' habit of drinking wine in a barbaric way, one can hardly say that the audience resonated with this problem. A couple of years later, perhaps in the 410s BC however, Euripides' Cyclops, by staging these questions and

25 See Hom. Od. 9. 196-215; E. Cyc. 411, cf. 141.

26 Hom. Od. 9.386-387 (transl. by Ian Johnston).

27 See KPS (pp. 213, 218-221); $\operatorname{Tr} G F$ I. (pp. 85-87). We cannot say for certain, however, Cratinus' or Aristias' play was written earlier, cf. KPS (p. 219, n. 3).

28 Ath. 10.426. See for example: Murray (1990: pp. 3-10). On the possible connection between Aristias F 4 and E. Cyc. 558, see HL ad loc.

29 Hall (1989: pp. 133-143). Cf. Pl. Lg. 637e. 
ambivalences, wove the intertextual - and by that time intertheatrical ${ }^{30}$ - tissue of the text further and not long after gave impetus to the great innovators of the turn of the $4^{\text {th }}$ century, Timotheus and Philoxenus of Cythera to create the new romantic figure of Polyphemus mousikos ${ }^{31}$ - opposite, in a way, to the Euripidean Polyphemus amousikos.

\section{Metamusical play beyond or embedded in the formal components of the musical performance}

The performance of Euripides' Cyclops enters into the musical landspace in the parodos. As clearly shown by the text, this choral dance of the satyr choreuts was flamboyant. The chorus sings and dances accompanied by the aulos (and perhaps by drums, too) in the presence of the statue of Dionysus while they complain that there is no song, no dance (choros, 63) here, no music of drums (tympanon, 65), no Dionysus (63). The sikinnis announced (37) by Silenus and compared to the komos of the good old days (39) is thus, though it is danced right before our eyes, non-existent, ${ }^{32}$ or, rather, it is not what it seems. The highly mimetic character of the swirling-leaping, boisterous dance imitating the movements of animals (sheep and rams strayed from the flock) and shepherd chas-

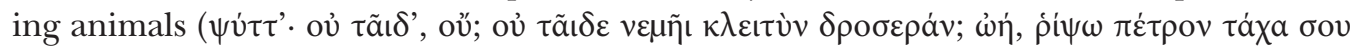
49-51) may have something to do with hyporchèma. ${ }^{33}$ It seems reasonable to assume that the celebrated fragment (Pindar fr. 107 Maehler $=$ Simonides fr. 255 Poltera) identified by Plutarch as a hyporchèma provides a typical example for this type of choral dance. ${ }^{34}$

30 Cf. Revermann (2006: p. 106).

31 The cyclops of Euripides singing vulgarly on stage (see below) was some years later presented as a kithara-singer in Philoxenus' dithyramb Cyclops or Galatea (PMG 815-824). As neatly summed up by Modini (2019), the biographical anecdote on the composition connected to Philoxenus' stay in the court of Dionysius the Elder “originated most probably from the attempt to explain the poem's innovative treatment of the myth of Polyphemus: as far as we can reconstruct, in the Cyclops Philoxenus introduced for the first time the motif of Polyphemus' love for Galatea, later on taken up and developed by Hellenistic authors" (p. 66), and we may add, the motif of Polyphemus in love is closely linked to the figure of Polyphemus mousikos. For Philoxenus' Cyclops see Power (2013) and LeVen (2014: pp. 113-149, with earlier literature). On Hellenistic Polyphemus, see Hordern (2004). On Timotheus' nomos, see note 52, below.

32 Cf. Bierl (2009: p. 59) on the parodos of the Cyclops: "In the same parodos the satyrs give a typically negative choral projection that nevertheless functions as self-reference to their own dance, singing, and music-making."

33 D'Alessio (2020: p. 69, n. 32): "The attribution of Bacch. fr. 16 M to the Hyporchemes, based on metrical grounds, is very uncertain (Hephaestion tends to refer to the first poem within a book with the feature he mentions, and the assumption is that it seems more likely that the book opened with the very famous and widely quoted poem whose incipit is preserved in fr. $15 \mathrm{M}$. Anyway, both arguments are not watertight: e.g. the poem opening with fr. $15 \mathrm{M}$ might not have been entirely in cretics)." Cf. Aristox. fr. 103 Wehrli = Ath. 630c-e, with Bierl (2009: pp. 81-82): "[T]he comic chorus comes fairly close to the chorus of the satyr play. Both, like the hyporcheme, were especially marked by rapid mimetic movements with a performatively sung verbal accompaniment. (...) In delivering its songs it does something: it searches, it runs, it hunts, it pursues, it flees, it curses, and it jumps and dances. But as soon as the tragic chorus lays aside its usual attitude and resorts to its very own dance, in the so-called hyporcheme it resembles the other two genres very closely."

Plu. Quaest. conv. 9,15, 748a-d. Cf. Ath. 5,181b; Eust. Il. 1166,48-49 (Van der Valk 1987: 4,269,17-20). 
On the one hand, the argument in Plutarch's last Table Talk reveals that mimesis in this highly energetic form of choral dance, as D'Alessio puts it, "involves imitation of animals and, more specifically, imitation of hunting animals." On the other, "the kind of ancient dance closest to Plutarch's hyporchematic fragment, which was meant to accompany the performance of a dance imitating the movements of hunting animals, might indeed have been the sikinnis." 35 To this we may add the close intertextual ties between the parodos-sikinnis of Cyclops and the hyporchēma in Pratinas' satyr-play (PMG 708) as already pointed out by D'Alessio in an earlier paper. ${ }^{36}$ If his recent arguments on the Pratinean authorship of the 'Pindaric-Simonidean-Bacchylidean' fragment are correct, we now have two 'hyporchematic' choral odes from Pratinas' satyr-drama(s) as antecedents to the 'non existent' hyporchematic parodos-sikinnis of Euripides' Cyclops. ${ }^{37}$

After telling how Polyphemus devoured two of his companions, Odysseus promptly shares the idea with the satyrs, who, showing that they understand the point of the story, even if it is not told in its entirety, express their excitement with a musical simile: $\lambda \dot{\varepsilon} \gamma^{\prime}$, $\omega \varsigma$

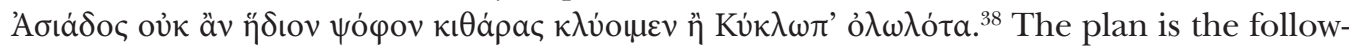
ing: the creature who completely lacks refinement must be lured into the culture of mousike , first and foremost into the world of the symposia..$^{39}$ Odysseus would get Polyphemus drunk with the wonderfully fine-tasting wine received from Maron, the son of Dionysus. After the giant was intoxicated enough, he also would go, of course,${ }^{40}$ to see his fellow cyclopes and invite them to join the kommos as an ordinary Greek would have do inspired by Dionysus. ${ }^{41}$ But Odysseus will intervene in the right moment and divert him from the komos. ${ }^{42}$ Thus, the revenge is made possible by the oddly close (but soon to be broken) ties created by Euripides between the Greek symposium and the post-sympotic ritualistic processional singing and dancing in drunken revelry. After getting drunk for the first

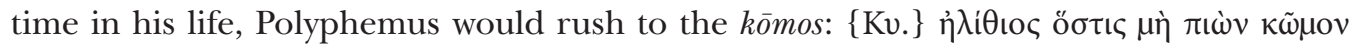
$\varphi \iota \lambda \varepsilon \tilde{\imath}$ (537). Though khoros and kōmos are distinct forms of singing and dancing, ${ }^{43}$ there are various connections between komasts and choreuts, and not just in the theatre. As Gregory Nagy writes "[t]o the extent that the kōmos is a group of male performers who sing and dance in a space (real or notional) that is sacred to Dionysus, it can be considered a subcategory of the khoros." ${ }^{44}$ Consequently, this imagined kōmos, thwarted at the

35 D'Alessio (2020: pp. 75, 78). The link between animals' hunting and sikinnis is severed by Ath. 14.630b-c based on Aristoxenus and confirmed by the mimetic dance (also a sikinnis) of S. Ich. 176-202, where the satyrs hunt for Apollo's cattle as hounds. Cf. Voelke (2001: pp. 170-172).

D'Alessio (2007: p. 114).

On the parodos, cf. OSC ad loc.; HL (pp. 98-103).

Cf. HL ad loc. (with references).

The extent to which the ogre lacks cultural refinement is obvious in his "philosophy of life" - an idea that is utterly scandalous (though probably well known) for the Athenian audience (11. 316-355).

Odysseus and, presumably, the audience think of the kōmos as a natural extension of the symposium.

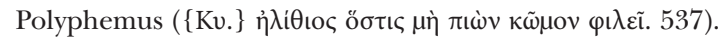

And indeed, while he is drinking the wine, he praises Dionysus as a true follower (415).

Cf. e.g. Shaw (2014: p. 26).

Nagy (2007: p. 212). Brief definitions of khoros and kōmos and their relation: Nagy (2011: p. 182). See now, 
right moment by Odysseus, from our perspective, means the following. The par excellence aristocratic post-sympotic Dionysiac ritual performed on an akhoros land may be seen as a 'native' kind of civic khoreia conceived but not born, and, at the same time, it is yet another example, after the satyrs', of a non-existing dance 'performed' (i.e. finally not performed) by the cyclopes. Odysseus will suggest that it would be in vain to share the wine with the other cyclopes, as he would be left with less, he could consume on his own. Polyphemus, of course, is persuaded to stay, since he is, as we have seen earlier, without mores, so much so that even the concept of xenia is unknown to him. Therefore, he will not lead a kōmos, rather, he stays in his cave and falls into a drunken sleep. Upon hearing the details of the plan, the satyrs promise their help. Then, they break out in a jubilant song and dance.

The third ${ }^{45}$ performance of the satyrs' choreia is the musical and poetic climax of the play. It is a song-and-dance consisting of four short movements. ${ }^{46}$ The proōdos (483-494) and the first strophe (495-502) are performed by the satyrs, the second strophe (503$510)$ by Polyphemus and finally the third strophe $(511-518)$ by the satyrs. There are two reasons as to why this can be viewed as the musico-poetical climax of the play. Firstly, because the texts of the three successive strophes enumerate three different characteristic features of Greek song culture. Here, the parodistic tone is not only revealed by the text, but also the identical meter of the three strophes which is very rare in drama. ${ }^{47}$ Secondly, it could be considered a climax, because the cacophony of Polyphemus is performed as a musical and acoustical counterpoint in the second strophe. The amoibaion of Greek drama is defined as a lyric interchange between characters or between character and chorus where both parts are sung. ${ }^{48}$ Here, the musical form turns into its opposite since one of the parts of this antiphonal singing is cacophony, not music. Let us begin with the latter.

Here, the satyrs reflect on the problem of staging an epic tale within the medium of

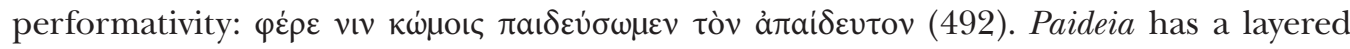
meaning, referring to the upbringing worthy of a free citizen and also to education, culture, social convenience and behaviour. ${ }^{49}$ It would thus be hard to translate the nuances and cultural overtones expressed in this thick formulation of the idea. The satyrs cry out enthusiastically and encouragingly: come on, let us educate the uneducated with kōmos! Cultural education (paideia) will be carried out by Dionysiac kōmos-processions

Olsen (2020: pp. 101-111, esp. 108-109, with further literature). On kōmos and symposion in general, see Pütz (2003: pp. 1-8) and Rothwell (2007: pp. 7-12). Cf. Shaw (2014: p. 26): "Pratinas' chorus of satyrs employs elements associated with comedy, satyr drama, and dithyramb, but they also distinguish their performance from the new theatrical dithyramb, thereby differentiating khoros from kômos."

45 The first was the parodos-sikinnis discussed briefly, the second (=1st stasimon, 356-374) was not discussed here: it is the part sustaining the convention of time on the stage. On the form, see HL (p. 173).

46 Cf. OSC (pp. 191-192); HL (pp. 199, 203-204); Rossi (1971: pp. 11-23).

47 Cf. OSC (p. 192). It is likely that the characteristic metre, if any, of the three song types was different.

48 On the amoibaion see Popp (1971) and Battezzato (2005). Form: proōidos followed by three subsequent strophes in the same metre (without antistrophes). There are no other examples to this form in the extant corpus of Greek drama.

49 See for example (only with regards to the Cyclops): Konstan (1990). 
of satyr-choreutai. To made the sous-entendu explicit: teach him how to march in the rambunctious procession of the kōmos, intoxicated by wine, performing song and dances celebrating Dionysus! As we have done so in times past, when Dionysus led our kōmos to the home of the nymph Althaia (39). Teach him a lesson by letting himself be dissuaded, driven by his individuality, of taking part in a 'real' communal Greek kōmos!

The other remarkable moment of the amoibaion is the acoustic and musical counterpoint of the satyrs' song and dance. As one of the very few stage directions found in the manuscripts, in line 485 we read the following: ( $\omega \dot{\delta} \delta \grave{\varepsilon} \varepsilon \delta$ o $\theta \varepsilon v$ ) (song [is to be heard] from within). ${ }^{50}$ The satyrs, upon beginning their excited, jubilant song, also give voice to what they hear (together with the audience). Silence! Silence! There comes the giant,

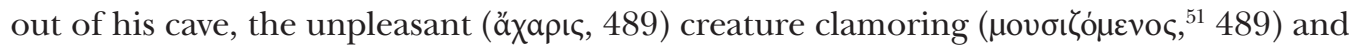

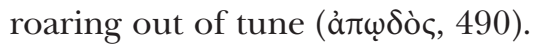

The word äxapıৎ continues and extends the musico-poetics of the alpha-privatives (akhoros, amousa) on the one hand, and variates it on the other. The apo- prefix with oid- gives here a meaning close to the alpha-privative: off key, out of music and tune. After the proode, in the first strophe, Polyphemus sings off key, then proceeds on to the next strophe, when he takes over singing (and dancing?) from the satyrs. The birth of a singing one-eyed giant, thanks to Dionysus, must have been an impressive musical and theatrical moment! ${ }^{52}$

As a choral song in the play Cyclops, the four 'movements' (proodos and the three stanzas in the same meter $)^{53}$ form a single unity. Separately, they all belong to the different forms of Greek choreia. The first is a parodistic makarismos, a ritual blessing related to either marital initiation or the initiation into the mysteries of Dionysus. ${ }^{54}$ The humorous cross-references of the first strophe are amplified in the third where the satyrs lead themselves into this new situation, and as they get into a more and more rampant mood (as something characteristic of ithyphallic satyrs) their choreia performance ends in an erotic, parodistic wedding song. The makarismos ending in a hymenaios as a musical form however is interrupted in the middle strophe by a parodistic kōmos of the by now solidly

50 In codex L (Florence, Biblioteca Laurenziana 32.2, early $\left.14^{\text {th }}\right)$, cf. P.Oxy 4545, col. ii, fr. $2\left(4^{\text {th }}\right.$ c. AD): $\omega t \delta \eta$ $\varepsilon[\ldots$ Later additions to performance texts? Cf. Taplin (1977).

51 The -i $\zeta \omega$ - denominative suffix from proper names may have a pejorative overtone, cf. $\mu \eta \delta i \zeta \omega, \lambda \alpha \kappa \omega v i \zeta \omega$ etc.

52 On the romantic Polyphemus mousikos invented by Philoxenus, see note 31, above. One of the few fragments known from Timotheus' Cyclops - more like a nomos, than a dithyramb, cf. Power (2013) - is

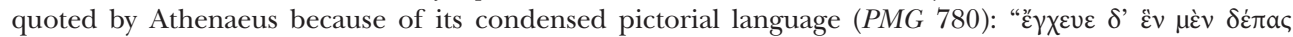

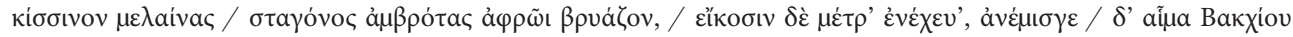

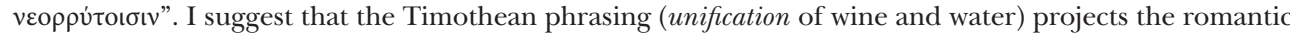
figure of Polyphemus, infatuated with a nymph whose tears are induced because of unrequited love onto the brutish and drunken Polyphemus-figure of the Odyssean adventure. The two figures of Polyphemus, the old and the new stage character, the old and the new kind of performance, and, finally, the old and the new music intermingle within the media of mousike, just as wine and water. Cf. Hordern (2002).

53 Cf. OSC (p. 192); HL (p. 203).

54 A closer parallel (even linguistically): E. Ba. 74ff. Other examples for makarismos in Greek tragedy: Swift (2010: pp. 396-400) (= Table 4 [hymenaeus]). On the mystery makarismos, see for example: Graf \& Johnston (2007: pp. 131-132). On the sexual implications of the makarismos strophe: Slenders (2005: pp. 47-48). Cf. HL (p. 205, ad 495). 
intoxicated Polyphemus. A kaleidoscope of different musical 'genres' and effects: makarismos, kōmos, hymenaios, in anti-antiphonal interchange, intermingled with cacophony, conceived and performed as a unity of the third choral ode of the play.

The next step of the musico-cultural trip is the symposium-parody scene, borrowed from the comic stage, ${ }^{55}$ in which the symposiastes Polyphemus lies down and tries to learn the appropriate behaviour befitting culturally refined Greekness, and in which Odysseus and Silenus try to educate the giant on how to serve and drink wine properly. What was foreshadowed by the intensifying erotic undertones of the amoibaion, is now fully blown. Its comical nature also sheds light on the extreme abuse of sexual power. The intoxicated Polyphemus, who learns the role of the Greek symposiastes begins to hallucinate and mistakes the old and ugly Silenus for young and beautiful Ganymede (and thus himself for Zeus), he pulls him into his cave and rapes him to relieve his sexual tensions. At the level of what can be experienced as seen in the performance - and not at the level of the plot - at this moment and with this act, by evoking the mousikos figure of the par excellence Greek symposiastes who is abusing his power to an extreme extent, the revenge will be deserved.

The last but one step is the magical song, an epōde only referred by the satyrs in the finale of the play. The satyrs however, even though they promised to help in plunging the huge, burning stake into the sleeping giant's eye back out of the deal at the last minute. But, as they say, they know a magical incantation from Orpheus that could make the stake fly into the eye of the giant. ${ }^{56}$

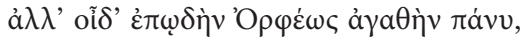

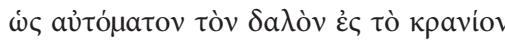

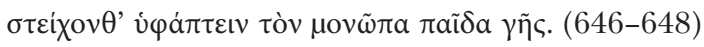
"Anyway, I know an incantation of Orpheus that's absolutely splendid, so that the brand will all by itself march up to his head and set the one-eyed son of the earth on fire."

These spoken lines about Orphic incantation, however, might have summoned up spells or incantations which cannot be heard on stage (as the blinding of the ogre cannot be seen) but the audience might be familiar with. ${ }^{57} \mathrm{~A}$ few lines later, the satyrs begin to sing and dance. ${ }^{58}$ Interjections, quickly alternating syllables and asyndetic imperatives display the rhythmic movement of the firebrand inside the cave, which is not seen on stage.

55 See Konstantakos (2005). Cf. Shaw (2014: pp. 115-116); Hamilton (1979).

56 Faraone (2008) is a detailed analysis of E. Cyc. 646-648 as evidence for Orphic charms (with links to magical papyri). Semenzato (2016: p. 308) takes the passage as an evidence for the power of Orpheus' music.

57 For $5^{\text {th }}$ BC incantations, see Faraone (2008: p. 132, n. 14).

58 On this fourth stasimon, see HL (pp. 237-238, "links to what we know of ancient work-songs"). 


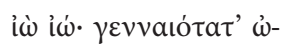

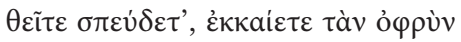

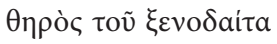

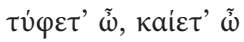

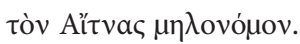

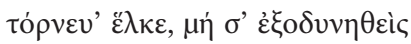

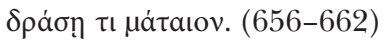

"O! O! Push it in most nobly,

Hurry, burn out the eye

Of the beast who dines on his guests!

O consume him in smoke! O burn

the shepherd of Etna!

Keep on twisting, keep on heaving it round, in case in his agony he

does something outrageous to you."

I suggest that this spell-like ${ }^{59}$ short choral song (656-662) may have served as a 'substitute' for an (occult?) Orphic incantation evoked in the mind of the audience. ${ }^{60}$ As a musical utterance it is (almost) the last of the series of musical forms and tones evoked in the play. This last choral song operates on two different levels. At the dramatic and emotional level, it not only establishes the time frame for the action inside the cave, but involves the audience in it. ${ }^{61}$ As an instance of the poetic function of mousike in this play, it enacts, in a subverted Orphic way, ${ }^{62}$ the power of mousike transformed before our eyes, as we have seen earlier, into the effective weapon against the amousikos.

The final flash of musical energy in Euripides' Cyclops demonstrates perhaps the flexibility of genres and the cross-generic dynamics of the culture of mousike in the last decades of the $5^{\text {th }}$ century. Upon hearing the painful cries of the cyclops ( $\ddot{\omega} \mu$ or,

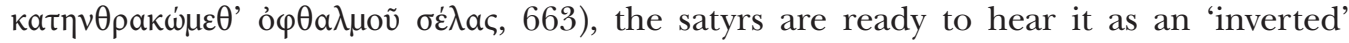

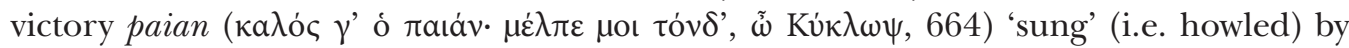
the enemy. ${ }^{63}$ Our satyrs, captives at this totally achoros place, who have complained (in singing-and-dancing) that there is no singing and dancing here, are now ready to hear

59 On commands (performative utterances) as speech-acts in magic spells, see e.g. Frankfurter (2001). Magical power by Orpheus' music: Simon. F274 Poltera (PMG 567), A. Ag. 1628-32, E. Alc. 357-59, Med. 543, Hipp. 953, Ba. 560-4, IA 1211-15. On some vases, we see satyrs among the listeners to Orpheus' music: Attic rf. hydria (Paris, Musée de Petit Palais 319) and column-krater (Portland, Art Museum 36.137, LIMC 'Orpheus' \#23), both by the Tarquinia 707 Painter, Attic rf. column-krater by the Agrigento Painter (Naples, Museo Archeologico 147739, LIMC 'Orpheus' \#22); cf. Lissarrague (1994: pp. 275-276).

60 Cf. OSC (pp. 217-218).

61 Odysseus enters the cave at the beginning of the choral section (653), Polyphemus, already blinded, exits at the end (663).

62 I do not mean to imply that this is an Orphic incantation, but that's what it's billed as by the satyrs. For an overview and function of asyndetic imperatives in Greek drama, see De Poli (2017); Eur. Cyc. 656-662 is, however, not included.

63 Cf. Eur. HF 751 and Antiope F223.51 (TrGF) where off-stage cry is described as $\mu \varepsilon \dot{\lambda o c . ~ I ~ a m ~ g r a t e f u l ~ t o ~ a n ~}$ anonymous reader for drawing these parallels to my attention. 
choral performance (paian) in every single utterance even in the ogre's howling. Mousike is back and, as a result, culture has won over the 'barbarians'.

\section{Conclusion}

My conclusion is that the performative/perceptive and emotional function of the "hidden chorus" - greatly illuminated by Laura Swift (2010) - in satyr-play is similar, but not identical, to that in tragedy. "We must read tragedy [and satyr-play] not only as drama, but also as choral song. (...) [T] o a Greek watching a play, the chorus is not just a convention of drama, it is something deeply familiar to him from his daily life. (...) [T] ragedy [and satyr-play] can make use of material derived from other types of lyric." ${ }^{64}$ Basic functional similarity between the choruses of tragedy and satyr-play seems to be natural as satyr-play, according to Demetrius' definition, is tragōidia paizousa. ${ }^{65}$ Difference can be explained by the fact that choral referentiality is, on the one hand, not limited to choral parts, and, on the other, it is capable, as we have seen, of both affirming and undermining choral authority at the same time, not only on the level of the plot but also on the level of reception aesthetics. There have been several analyses of the reception aesthetics and anthropological function of the satyr-play that followed the three tragedies at the Dionysia. ${ }^{66}$ In the Cyclops, it is mousike that represents the attitudes of the Athenian (and non-Athenian) audiences towards culture. Mousike, embodied by the satyrs, gives the viewers an outside perspective and transforms them into onlookers, then, in front of our eyes, they are reconstructed - though in a distorted manner, with some distance kept. ${ }^{67}$

It is largely accepted that satyr-play made possible for a male-dominated audience to recognise the suppressed satyrs in themselves. ${ }^{68}$ However, it seems that in Euripides's 'culturally refined' (mousikos) satyrs in the 5th century BC, with the Peloponnesian wars in the background, the viewers do not only recognise the satyr in themselves, but also themselves in the representation of the satyrs. They come across something they want to see themselves as and something they have to face. They see a creature who is innocent, beaming, reputable, and fallible, prone to and desiring sins and disorderly behaviour, constantly threatened, but always saved, wishing for his own happiness, and whose only duty would be to find safety and find defence with culture that manifests itself in mousike and choreia. But the question arises at the end of the play: does this defence evoked by flashing different kinds of songs still exist, and can this pursuit succeed?

64 Swift (2010: pp. 2-3, with my additions).

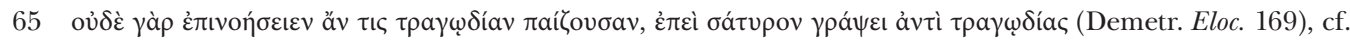
Laemmle (2013: pp. 53-54).

66 A good summary: OSC (pp. 25-28, cf. the previous summaries in n. 97).

67 Cf. Lissarrague (1990).

68 Griffith (2015: pp. 75-108 [2005]) highlights a remarkably strong parallel, the 19th-century American blackface minstrelsy (white actors with faces painted black) in the tradition of dance and musical performances. 


\section{Bibliography}

Aguirre, M., \& Buxton, R. (2020). Cyclops. The Myth and its Cultural History. Oxford: Oxford University Press.

Anderson, G. (2000). Fairy Tale in the Ancient World. London - New York: Routledge.

Bakola, E. (2010). Cratinus and the Art of Comedy. Oxford - New York: Oxford University Press.

Battezzato, L. (2005). Lyric. In J. Gregory (Ed.), A Companion to Greek Tragedy (pp. 149-166). Malden, MA - Oxford - Carlton: Blackwell.

Bierl, A. (2009). Ritual and Performativity: The Chorus in Old Comedy (transl. A. Hollmann). Cambridge, MA: Harvard University Press and the Center for Hellenic Studies.

Calame, C. (1977). Les choeurs de jeunes filles en Grèce archä̈que. Roma: Ed. dell'Ateneo \& Bizarri.

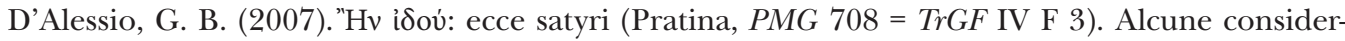
azioni sull'uso della deissi nei testi lirici e teatrali. In F. Perusino, \& M. Colantonio (Eds.), Dalla lirica corale alla poesia drammatica. Forme e funzioni del canto corale nella tragedia e nella commedia greca (pp. 95-128). Pisa: Edizioni ETS.

D'Alessio, G. B. (2020). Dancing with the dogs: mimetic dance and the hyporcheme (on Pind. fr. *107 M = Simonides 255 Poltera). In P. Agócs, \& L. Prauscello (Eds.), Simonides Lyricus: Essays on the 'other' classical choral lyric poet (Cambridge Classical Journal Suppl., 42; pp. 59-80). Cambridge: The Cambridge Philological Society.

De Poli, M. (2017). Electra Loves Asyndeton. A Survey on Asyndetic Series of Imperatives in Ancient Greek Drama. In M. De Poli (Ed.), Euripides. Stories, Texts E゚ Stagecraft (pp. 63-72). Padova: University Press.

Faraone, Ch. (2008). Mystery Cults and Incantations: Evidence for Orphic Charms in Euripides' Cyclops 646-648. Rheinisches Museum für Philologie, 151(2), 127-142.

Frankfurter, D. (2001). The Theory and Practice of the Magical Historiola in Ritual Spells. In M. W. Meyer, \& P. A. Mirecki (Eds.), Ancient Magic and Ritual Power (pp. 457-476). Leiden: Brill.

Giuliani, L. (2013). Image and Myth. A History of Pictorial Narration in Greek Art (transl. J. O'Donnell). Chicago - London: University of Chicago Press.

Graf, F., \& Johnston, S. I. (2007). Ritual Texts for the Afterlife. Orpheus and the Bacchic Gold Tablets. London - New York: Routledge.

Griffith, M. (2015). Greek Satyr Play. Five Studies. Berkeley, CA: California Classical Studies.

Hall, E. (1989). Inventing the barbarian: Greek self-definition through tragedy. Oxford: Clarendon Press. Halliwell, S. (2012). Amousia: Living without the Muses. In I. Sluiter, \& R. M. Rosen (Eds.), Aesthetic Value in Classical Antiquity (pp. 15-45). Leiden - Boston: Brill.

Hamilton, R. (1979). Euripides' Cyclopean symposium. Phoenix, 33, 287-292.

Hansen, W. (2002). Ariadne's Thread: A Guide to the International Tales Found in Classical Literature. Ithaca - London: Cornell University Press.

Harrison, G. W. M. (2005). Positioning of satyr drama and characterization in the Cyclops. In G. W. M. Harrison (Ed.), Satyr Drama. Tragedy at Play (pp. 237-258). Swansea: The Classical Press of Wales. Heubeck, A., \& Hoekstra, A. (1989). A Commentary on Homer's Odyssey, II: Books IX-XVI. Oxford: Oxford University Press.

HL = Hunter, R., \& Laemmle, R. (Eds.). (2020). Euripides: Cyclops. Cambridge: Cambridge University Press. 
Hordern, J. H. (2002). The Fragments of Timotheus of Miletus. Oxford: Oxford University Press.

Hordern, J. H. (2004). Cyclopea: Philoxenus, Theocritus, Callimachus, Bion. The Classical Quarterly, 54, 285-292.

Konstan, D. (1990). An Anthropology of Euripides' Kyklōps. In J. J. Winkler, \& F. I. Zeitlin (Eds.), Nothing to do with Dionysos? Athenian drama in its social context (pp. 207-227). Princeton: Princeton University Press.

Konstantakos, I. M. (2005). Staged Symposia in Greek Comedy. Mnemosyne, 58(2), 183-217.

Koster, W. J. W. (Ed.). (1975). Prolegomena de comoedia (Vol. I). Groningen: Bouma's Boekhuis.

KPS = Krumeich, R., Pechstein, N., \& Seidensticker, B. (Eds.). (1999). Das griechische Satyrspiel. Darmstadt: Wissenschaftliche Buchgesellschaft.

Laemmle, R. (2013). Poetik des Satyrspiels. Heidelberg: Universitätsverlag Winter.

LeVen, P. A. (2014). The Many-Headed Muse. Tradition and Innovation in Late Classical Greek Lyric Poetry. Cambridge: Cambridge University Press.

LIMC = Lexicon Iconographicum Mythologiae Classicae. (1981-1999). Zürich: Artemis Verlag.

Lissarrague, F. (1990). Why Satyrs Are Good to Represent. In J. J. Winkler, \& F. I. Zeitlin (Eds.), Nothing to do with Dionysos? Athenian drama in its social context (pp. 228-236). Princeton: Princeton University Press.

Lissarrague, F. (1994). Orphée mis à mort. Musica e Storia, 2, 269-307.

Mastromarco, G. (1998). La degradazione del mostro: la maschera del Ciclope nella commedia e nel dramma satiresco del quinto secolo a.C. In A. M. Belardinelli et al. (Eds.), Tessere: frammenti della commmedia greca: studi e commenti (pp. 9-42). Bari: Adriatica editrice.

Modini, F. (2019). The Cyclops' Revenge. Aelius Aristides on Plato, Philoxenus, and New Music. Greek and Roman Musical Studies, 7, 51-69.

Murray, O. (1990). Sympotica. A Symposium on the Symposion. Oxford: Oxford University Press.

Nagy, G. (2007). Did Sappho and Alcaeus Ever Meet? Symmetries of Myth and Ritual in Performing the Songs of Ancient Lesbos. In A. Bierl, R. Laemmle, \& K. Wesselmann (Eds.), Literatur und Religion I: Wege zu einer mythisch-rituellen Poetik bei den Griechen (pp. 211-69). Berlin - New York: De Gruyter.

Nagy, G. (2011). A second look at the poetics of re-enactment in Ode 13 of Bacchylides. In L. Athanassaki, \& E. Bowie (Eds.), Archaic and Classical Choral Song. Performance, Politics and Dissemination (pp. 173-206). Berlin - Boston: De Gruyter.

Olsen, S. (2020). Solo Dance in Archaic and Classical Greek Literature: Representing the Unruly Body. New York: Cambridge University Press.

Olson, S. D. (2007). Broken Laughter. Select Fragments of Greek Comedy. Oxford: Oxford University Press. OSC = O’Sullivan, P., \& Collard, Ch. (Eds. \& Transl. \& Comm.). (2013). Euripides: Cyclops and Major Fragments of Greek Satyric Drama. Oxford: Oxbow Books.

$P C G=$ Kassel, R. \& Austin, C. (Eds.). (1983-2001). Poetae Comici Graeci. Berlin: De Gruyter.

$P M G=$ Page, D. L. (1962). Poetae melici Graeci. Oxford: Oxford University Press.

Pöhlmann, E. (2015). Epicharmus and Aeschylus on Stage in Syracuse in the 5th Century. Greek and Roman Musical Studies, 3, 137-166.

Popp, H. (1971). Das Amoibaion. In W. Jens (Ed.), Die Bauformen der griechischen Tragödie (pp. 221-276). München: Wilhelm Fink.

Power, T. (2013). Kyklops Kitharoidos: Dithyramb and Nomos in Play. In B. Kowalzig, \& P. Wilson (Eds.), Dithyramb in Context (pp. 232-256). Oxford: Oxford University Press. 
Prauscello, L. (2014). Performing Citizenship in Plato's Laws. Cambridge: Cambridge University Press.

Pütz, B. (2003). The Symposium and Komos in Aristophanes. Stuttgart - Weimar: J. B. Metzger.

Revermann, M. (2006). The Competence of Theatre Audiences in Fifth- and Fourth-Century Athens. The Journal of Hellenic Studies, 126, 99-124.

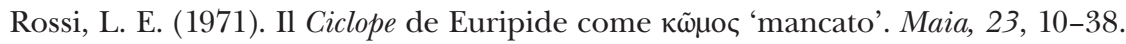

Rothwell, Jr. K. S. (2007). Nature, Culture, and the Origins of Greek Comedy. A Study of Animal Choruses. New York: Cambridge University Press.

Seaford, R. (Ed. \& Comm.). (1984). Euripides: Cyclops. Oxford: Oxford University Press.

Semenzato, C. (2016). Orpheus and mousikê in Greek Tragedy. Trends in Classics, 8, 295-316.

Shaw, C. A. (2014). Satyric Play. The Evolution of Greek Comedy and Satyr Drama. New York: Oxford University Press.

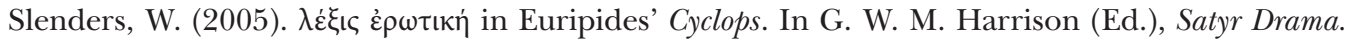
Tragedy at Play (pp. 39-52). Swansea: The Classical Press of Wales.

Squire, M. (2009). Image and Text in Graeco-Roman Antiquity. Cambridge: Cambridge University Press.

Storey, I. C. (Ed. \& Transl.). (2011). Fragments of Old Comedy I-III. Cambridge, MA - London: Harvard University Press.

Swift, L. A. (2010). The Hidden Chorus. Echoes of Genre in Tragic Lyric. New York: Oxford University Press.

Taplin, O. (1977). Did Greek Dramatists Write Stage Instructions? Proceedings of the Cambridge Philological Society, 23, 121-132.

Touchefeu-Meynier, O. (1997). Polyphemos I. In LIMC (Vol. VIII, 1 Suppl.; pp. 1011-1019).

$\operatorname{Tr} G F=$ Kannicht, R., Snell, B. \& Radt, S. (Eds.). (1971-2004). Tragicorum Graecorum Fragmenta. Göttingen: Vandenhoeck und Ruprecht.

Uther, H-J. (2004). The Types of International Folktales. A Classification and Bibliography. Helsinki: Suomalainen Tiedeakatemia.

Van der Valk, M. (Ed.). (1987). Eustathii Archiepiscopi Thessalonicensis Commentarii ad Homeri Iliadem pertinentes (Vol. 4). Lugduni Batavorum: Brill.

Voelke, P. (2001). Un théâtre de la marge. Aspects figuratifs et configurationnels du drame satyrique dans l'Athènes classique. Bari: Levante editori.

Weiss, N. A. (2018). The Music of Tragedy. Performance and Imagination in Euripidean Theater. Oakland, CA: University of California Press. 
Prof. András Kárpáti / karpati.andras@pte.hu

Department of Classical Philology

University of Pécs, Institute for Philosophy, Art Theories, and Classical Studies

Ifjúság útja 6, 7622 Pécs, Hungary 
